\title{
Morphological and morphometric analysis from the heart of Caracara plancus (Carcará)
}

\author{
MIGUEL, R. D. S. ${ }^{1}$, REINALDO, R. C. P. S. $^{2}$, FRAGA, K. B. ${ }^{3}$, \\ GALVÃO, A. P. O. ${ }^{4}$ SILVA, J. A. C. ${ }^{5}$ XAVIER, J. E. ${ }^{6}$ and MAGALHÃES, C. P. ${ }^{*}$ *
}

\begin{abstract}
${ }^{1}$ Student of Biology, Academic Center of Vitória, Federal University of Pernambuco CAV-UFPE, Street Alto do Reservatório, s/n, Bela Vista, CEP 55608-680, Vitória de Santo Antão, PE, Brasil

${ }^{2}$ Master's student in the Graduate Program in Botany, Federal Rural University of Pernambuco, Street Professor Moraes Rego, 1235, Cidade Universitária, CEP 50670-901, Recife, PE, Brasil ${ }^{3}$ Master of health and environment, Academic Center of Vitória, Federal University of Pernambuco CAV-UFPE, Street Alto do Reservatório, s/n, Bela Vista, CEP 55608-680, Vitória de Santo Antão, PE, Brasil

${ }^{4}$ Technician in Anatomy and necropsy, Academic Center of Vitória, Federal University of Pernambuco CAV-UFPE, Street Alto do Reservatório, s/n, Bela Vista, CEP 55608-680, Vitória de Santo Antão, PE, Brasil

${ }^{5}$ Majoring in Biological Sciences from the Federal University of Pernambuco, Street Professor Moraes Rego, 1235 , Cidade Universitária, CEP 50670-901, Recife, PE, Brasil

${ }^{6}$ Student of Biology, Academic Center of Vitória, Federal University of Pernambuco CAV-UFPE. Street Alto do Reservatório, s/n, Bela Vista, CEP 55608-680, Vitória de Santo Antão, PE, Brasil

${ }^{7}$ Associate Professor of Human Anatomy, Academic Center of Vitória, Federal University of Pernambuco CAV-UFPE. Street Alto do Reservatório, s/n, Bela Vista, CEP 55608-680, Vitória de Santo Antão, PE, Brasil *E-mail: peixotocarolted@hotmail.com
\end{abstract}

\begin{abstract}
Introduction: Caracara plancus, popularly known as Carcará, is a bird with broad geographic distribution, occurring from the southern United States to Argentina. Owing to importance of the heart during the flight and the lack of studies of this body in caracaras, this research aimed to conduct the description of the morphology and internal and external morphology heart Caracara plancus. Materials and Methods: Using a magnifying glass (TECNIVAL, SQF-F), precision scale and steel caliper, the heart three caracaras were described morphologically, weighed and measured. Results: The weight of hearts averaged 7,246g $\pm 0,518 \mathrm{~g}$. The mean side-to-side axis was $2,196 \mathrm{~cm} \pm 0,085 \mathrm{~cm}$ and $3,366 \mathrm{~cm} \pm 0,036 \mathrm{~cm}$ the longitudinal axis. In the side wall of the right ventricle was obtained the value of $0,185 \mathrm{~cm} \pm 0,035 \mathrm{~cm}$ in the lateral wall of the left ventricle $0,59 \mathrm{~cm} \pm 0,014 \mathrm{~cm}$ and interventricular septum $0,014 \mathrm{~cm} \pm 0.52 \mathrm{~cm}$. The heart of Carcará has no anterior interventricular groove; however there is the presence of the posterior interventricular sulcus. Internally, the left ventricle was observed, the presence of atrioventricular valves formed by connective tissue 18 tendinous cords, papillary muscles and a bridge crests. In the right ventricle, the atrioventricular valve was formed by muscle tissue and did not submit chordae, papillary muscles, crests or bridge. Conclusion: The heart of Carcará features in its morphology similar to the hearts of other birds and can be checked one right atrioventricular valve constituted by muscle tissue.
\end{abstract}

Keywords: Carcará, heart, birds.

\section{Introduction}

The Caracara plancus, popularly known as Carcará, is a bird of prey belonging to the family Falconidae (MORISON, 2006) with broad geographic distribution, occurring from the southern United States to Argentina (ALMEIDA, SOUZA, AGUILAR et al., 2009). They inhabit open environments or partially open as savanna, savanna, grasslands, cultivated fields, marshes, road, cities and rural areas. In southern South America, the Carcará habitat has expanded along with the increase in human activity (SIGRIST, 2006). Although studies on the feeding habits of this species are restricted to observations, it can be said that the Carcará has omnivorous diet, since feed carrion, live prey, fruit, etc. (HAVERSCHMIDT 1947; GLAZENER, 1964; AZATEGUI, 1975; RICHMOND, 1976; LAYNE, LOHNER and WINGARNER, 1977; WHITACRE, UKRAIN and FALXA, 1982; WALLACE and

TEMPLE, 1987; DICKINSON, 1995; YOSEF and YOSEF, 1992; SIGRIST 2006 ; SICK, 1988). Sick (1988, 2001). Due to this complex food habit, this species has a higher risk factor for acquiring certain parasitic diseases, such as, for example, toxoplasmosis (SICK, 2001; VITALIANO et al., 2010).

Is well known that birds require morphological and physiologic alterations that might allow the flight. One of the most common and well known examples are the pneumatic bones. However, in practice the flight increased demand suffering energy is neededto this end more significant changes in the respiratory and cardiovascular system. The heart of the birds is a medium structure, whose aortic arch is facing right from where the first arterial branches (GETTY, 1986; GRASSÉ, 1950; KOCH, 1973). As in mammals, the heart of the birds has double and complete circulation. Due 
to its importance in the lives of vertebrates and the lack of studies on the Carcará heart anatomy, this study aimed to make the description of the morphology and internal and external morphology heart Caracara plancus.

\section{Materials and Methods}

This research was performed in the Academic Center of Vitoria of the Federal University of Pernambuco (CAVUFPE), which is authorized by IBAMA-PE and passed by the Ethics Committee of the institution, protocol 23076.016446/2012-10. For carry out this study, we used three captive Carcarás. They were anesthetized with atropine and ketamine at a dose of $1.6 \mathrm{mg} / \mathrm{kg}$ and $30 \mathrm{mg} / \mathrm{kg}$, respectively, administered in the superficial pectoral muscle (intramuscularly). Then, an incision was made in the pectoral muscle to access the chest cavity to remove the heart. After dissection of the layers of fat and the pericardium, the hearts were weighed using precision scales 0.0001 (CELTA, $2104 \mathrm{~N})$. Then the hearts were measured with a steel caliper $(0.05 \times 150 \mathrm{~mm})$ for measurement of lateral-lateral and longitudinal axes. The external morphological description by two researchers separately (double blind analysis) was performed. After reviews and measurements of the external morphology, the hearts were sectioned for description of internal morphology, where two hearts were sectioned in the frontal plane and in the transverse plane. With the aid of a magnifying glass (TECNIVAL, SQF-F) in increases of two to four times, two researchers (double blind analysis) described the internal morphology of that body. It was also measured the thickness of the ventricular walls and atrioventricular septal. After macroscopic analysis, a heart was histologically processed for analysis of atrioventricular valves. For this, the hearts were dehydrated in alcohol at increasing concentrations, diaphanized in xylene and embedded in paraffin. Afterwards, the blocks were cut on a microtome in a thickness of 5 microns and stained with Hematoxylin and Eosin. After staining, slides were photographed and evaluated for tissue type.

\section{Results}

The weight of the analysis showed that the hearts of Carcarás present mean $\pm 7,246 \mathrm{~g} 0,518 \mathrm{~g}$. In external morphology, performed with the use of a caliper, we found that the average in the side-to-side axis was $2,196 \mathrm{~cm} \pm 0,085 \mathrm{~cm}$ and $3,366 \mathrm{~cm} \pm 0.036 \mathrm{~cm}$ in the longitudinal axis (Figure la). Morphologically, the heart of Carcará had no anterior interventricular sulcus externally separating the right and left ventricles, as in mammals, but another groove passing the right of the interventricular septum. Conversely, posterior interventricular groove, and this was passed through this groove a coronary vessel. He also presented two atria, one in atrium, which were separated from the ventricles by atrioventricular groove. In internal morphology was possible to verify the presence of pectinal muscles in the atria and right and left atria (Figure lb). It was found in the left ventricle, the existence of atrioventricular valves composed of connective tissue in the right ventricle while the valve was only and is formed by muscle tissue (Figure le and f).The left ventricle,
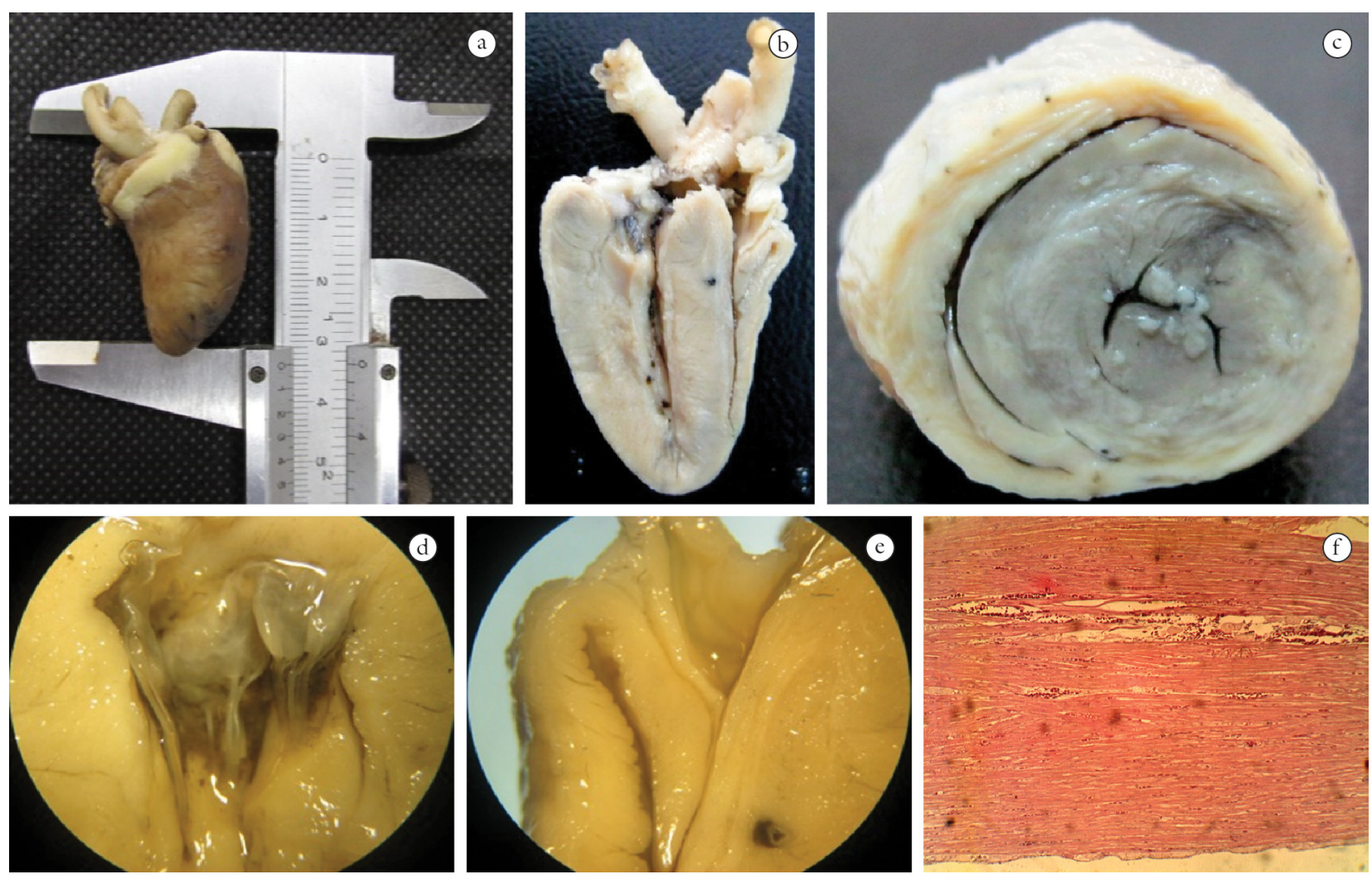

Figure 1. Heart Photography of Caracara plancus: a- Heart longitudinal axis; b- frontal section; c- Transverse section; d and e- Frontal section heart of Caracara plancus through a magnifying; $d$ - left atrioventricular valve; e- Right atrioventricular valve; f-Photomicrograph of the enlarged heart in 40X. 
had the presence of ridges and papillary muscles which were part of the 18 existing chordal, unlike the right ventricle, which did not submit papillary muscles (Figure ld), crests or chordal, but with the presence of a septum-marginal trabecular (bridge). The lateral wall of the right ventricle measured $0,185 \mathrm{~cm} \pm 0,035 \mathrm{~cm}$ thick, whereas the lateral wall of the left ventricle was equal to $\pm 0,59 \mathrm{~cm} 0,014 \mathrm{~cm}$ and the interventricular septum $0,014 \mathrm{~cm} \pm 0.52 \mathrm{~cm}$. Histological analysis showed that the right atrioventricular valve is formed by muscle tissue, while the right by connective tissue.

\section{Discussion}

The heart of Carcará submitted four heart chambers, the same one detected in other birds such as, for example, Struthio camelus, ostrich (HENRÍQUEZ, HENRÍQUEZ AND OLAVE, 2012; SOARES et al., 2010). Despite the great similarity between the heart of birds and mammals (DYCE, SACK and WENSING, 2004), the heart of Carcará differentiates the latter mostly by the absence of a right atrioventricular valve in connective tissue, which is muscular valve. Even this feature is different from the heart of mammals, it seems to be common in birds (HENRÍQUEZ, HENRÍQUEZ AND OLAVE, 2012), possibly to increase efficiency in preventing blood reflux between the atrium and right ventricle and vice versa. The left ventricular wall of the heart Carcará shown to be greater than the right ventricle, just as points Baumel (1986) states that when the left ventricular wall is three to four times greater than the right ventricle. In the analyzed hearts, the right coronary artery passes in a groove right of the interventricular septum. The name "interventricular groove" suggests that this groove is between the ventricles, and this groove in the heart of Southern Carcará was not going over the interventricular septum, as in mammals. With this would be a mistake to call this anterior interventricular groove. This same groove pattern was found by Getty (1986) working with chickens, but he did not named.

\section{Conclusions}

From this work it was found that the heart of the Caracara plancus presents internal and external morphology quite similar to that of other birds. One of these similarities is the presence of a muscle right atrioventricular valve and the target finding possible physiological studies which provide greater degree of certainty that the advantages afforded morphology for birds.

Acknowledgements: We would like to thank the Academic Center of Vitória (CAV), campus of the Federal University of Pernambuco, for giving the location and materials employed in this research. IBAMA-PE for having given us the Carcarás used. And teachers, technicians and students from the CAV who participated directly or indirectly in this research.

\section{References}

ALMEIDA, BJM., SOUZA, AG., AGUILAR, JMRE. and FERRARI, SF. Abundância comparativa dos registros do Carcará (Caracara plancus Miller 1777) feitos no período de 2004-2005 e de 2008 a Junho de 2009, na praia de Atalaia, Aracajú- Sergipe, 2009. In Anais do III Congresso Latino Americano de Ecologia. São Lourenço, MG: Sociedade de Ecologia do Brasil, 2009. 3 p. [Resumos].
AZATEGUI, A. Datos sobre aves de Santa Isabel (CoH rdoba). Revista de Ornitología Neotropical, 1975, vol. 11, n. 4, p. 321.

BAUMEL, JJ. Anatomia dos animais domésticos. Rio de Janeiro: Guanabara Koogan, 1986.

DICKINSON, VM. Red imported fire ant predation on Crested Caracara nestlings in South Texas. Wilson Bulletin, 1995.

DYCE, KM., SACK, MO. and WENSING, CJG. Tratado de anatomia veterinária. Rio de Janeiro: Elsevier, 2004.

GETTY, R. Sisson/Grossman's anatomia dos animais domésticos. Rio de Janeiro: Interamericana, 1986.

GLAZENER, WC. Note on the feeding habits of the Caracara in South Texas. Condor, 1964, vol. 66, p. 162-163.

GRASSÉ, PP. Traité de zoologie. Paris: Masson ET Cie, 1950.

HAVERSCHMIDT, F. The black vulture and the Caracara as vegetarians. Condor, 1947, vol. 49, p. 210.

HENRÍQUEZ, H., HENRÍQUEZ, J. and OLAVE, E. Patrón de distribuicion de las arterias coronarias y sus ramas ventriculares en el corazón de avestruz (Struthio canelus). International Journal of Morphology, 2012, vol. 30, n. 3, p. 1013-1018.

$\mathrm{KOCH}, \mathrm{T}$. Anatomy of the chicken and domestic birds. Ames, Iowa: The Iowa University Press, 1973.

LAYNE, JM., LOHNER, FE and WINGARNER, E. Birds and mammal predators of the Cattle Egret in Florida. Florida Field Naturalist, 1977, vol. 5, p. 1-4.

MORISON, JL. The crested caracara in the changing grasslands of Florida. In Proceedings of the Florida Dry Prairie Conference: land of fire and water: the Florida Dry Prairie Ecossystem, 2006. Sebring, Florida: E. O. Painter Printing Co., 2006. p. 211-215. [Resumos].

RICHMOND, AR. Feeding of nestlings by the Caracara in Costa Rica. Wilson Bulletin, 1976, vol. 88, n. 4, p. 667.

SIGRIST, T. Aves do Brasil: uma visão artística. Vinhedo: Avisbrasilis, 2006.

SICK, H. Ornitologia brasileira: uma introdução. Brasília: Editora Universidade de Brasília, 1988.

SICK, H. Onitologia brasileira. Rio de Janeiro: Nova Fronteira, 2001.

SOARES, GL., OLIVEIRA, D. and BARALDI-ARTONI, SM. Aspecto da anatomia do coração do Avestruz. Ars Veterinária. 2010, vol. 26, n. 1, p. 38-42.

VITALIANO, SN., MINEO, TWP., ANDRÉ, MR., MACHADO, RZ., MINEO, JR. and WERTHER, K. Experimental infection of Crested Caracara (Caracara plancus) with Toxoplasma gondii simulating natural conditions. Veterinary Parasitology, 2010, vol. 172, n. 1-2, p. 71-75. PMID: 20451327. http://dx.doi. org/10.1016/j.vetpar.2010.04.010.

WALLACE, MP. and TEMPLE, SA. Competitive interactions within and between species in a guild of avian scavengers. The Auk, 1987, vol. 104, p. 290-295.

WHITACRE, D., UKRAIN, D. and FALXA, G. Notes on the hunting behavior and diet of the Crested Caracara in northeastern Chiapas and Tabasco, Mexico. Wilson Bulletin, 1982, vol. 94, n. 4, p. 565-566.

YOSEF, R. and YOSEF, D. Hunting behavior of Audubon's Crested Caracara. Journal of Raptor Research, 1992, vol. 26, p. 100-101.

Received Dec. 10, 2013 Accepted Dec. 15, 2014 